\title{
Dietary tryptophan level and the enzymes of tryptophan NAD pathway
}

\author{
BY U. SATYANARAYANA AND B. S. NARASINGA RAO \\ National Institute of Nutrition, Indian Council of Medical Research, Jamai Osmania (P.O.), \\ Hyderabad-500 007, India
}

(Received 27 April 1978 - Accepted 31 March 1979)

1. Dietary tryptophan was found to regulate the activities of tryptophan oxygenase ( $E C$ I I 1 3.1.12) and quinolinate phosphoribosyltransferase $(E C$ 2.4.2a) in liver.

2. With increasing tryptophan concentration in the diet containing $100 \mathrm{~g} \mathrm{protein} / \mathrm{kg}$, tryptophan oxygenase activity increased while that of quinolinate phosphoribosyltransferase decreased. The response of these enzymes to dietary tryptophan at lower dietary protein level $(25 \mathrm{~g} / \mathrm{kg})$ was not significant.

3. Liver nicotinate phosphoribosyltransferase ( $E C$ 2.4.2. II) activity and kidney picolinate carboxylase (EC 4.I I I 45) activity were unaltered with different tryptophan concentrations in the diet.

4. The response of various biochemical measurements was dependent on the tryptophan intake and the changes were marked below and above the requirement level of tryptophan.

5. It is suggested that the urinary excretion of quinolinic acid and $N^{\prime}$-methylnicotinamide may be useful in assessing the tryptophan nutritional status and its requirement.

It has been recently reported (Satyanarayana \& Narasinga Rao, 1977) that quinolinate phosphoribosyltransferase (EC 2.4.2a) activity in livers of rats is inversely related to dietary protein level. It was also observed in this study that tryptophan oxygenase ( $E C$ I . I 3 I I I 2) activity increased with increasing dietary protein level, an observation in line with an earlier report (Chiancone, 1965). The observed enzymatic changes with alterations in the dietary protein level could be due to alterations in the intake of dietary tryptophan. The regulatory role of tryptophan on tryptophan oxygenase is well documented (Knox \& Mehler, 1951; Knox, 1966). The possibility of dietary tryptophan regulating the other important enzymes in this pathway, namely quinolinate phosphoribosyltransferase, picolinate carboxylase (EC 4.I.I.45) and nicotinate phosphoribosyltransferase $(E C$ 2.4.2. II) was therefore investigated. In addition to measuring these enzymes in liver and kidney of rats given varying levels of tryptophan at two protein levels, liver nicotinamide nucleotide levels and urinary excretion of tryptophan-nicotinic acid metabolites were measured in this study. The immediate effect of tryptophan administration on the activity of some of the enzymes of the pathway was also studied by administering L-tryptophan intraperitoneally to rats.

\section{MATERIALS AND METHODS}

Chemicals. [Carboxyl-14 C]nicotinic acid ( $1 \cdot 8 \mu \mathrm{Ci} / \mu \mathrm{mol})$ was obtained from Bhaba Atomic Research Centre, Trombay, India. Its purity was tested by paper chromatography using the solvent system of 3 parts of I M-ammonium acetate $(\mathrm{pH} 5 \cdot 0)$ and seven parts $95 \%(\mathrm{v} / \mathrm{v})$ ethanol. Quinolinic acid, nicotinic acid, 3-hydroxyanthranillic acid and ATP were purchased from Sigma Chemical Co. Ltd. St Louis, Missouri, USA. 5'-Phosphoribosyl-I-pyrophosphate (magnesium salt) was obtained from Calbiochem, La Jolla, California, USA.

Animals and diets. Young weanling albino rats of $2 \mathrm{I} d$ of age (inbred strain of National Institute of Nutrition, Hyderabad - 500 007) were used. They were distributed into six groups of ten rats each on the basis of body-weight and sex.

The composition of the diets fed to the various groups of rats is shown in Table I. Casein hydrolysate, free of tryptophan, was used as the protein (nitrogen $\times 6.25$ ) source. 
Table I. Composition of the diets $(\mathrm{g} / \mathrm{kg})$ given to groups of rats

\begin{tabular}{lcc}
\multicolumn{1}{c}{ Ingredient } & Group I & Group 3 \\
Casein hydrolysate & 30.5 & 122 \\
(Protein, N $\times 6.25)$ & $(25)$ & $(100)$ \\
Peanut oil & 50 & 50 \\
Salt mix* & 40 & 40 \\
Vitamin Mix $\dagger$ & IO & 10 \\
L-cystine & 2 & 2 \\
L-tryptophan & $0.3 \ddagger$ & 0.38 \\
Maize starch & 842 & 776
\end{tabular}

* US Pharmacopoeia XVII (1965).

+ National Academy of Sciences/National Research Council (1963).

¥ The diet given to group 2 contained $1 \cdot 2 \mathrm{~g}$ L-tryptophan $/ \mathrm{kg}$.

$\S$ The diets given to groups 4,5 and 6 contained $0 \cdot 6,1 \cdot 2$ and $2 \cdot 4 \mathrm{~g}$ L-tryptophan $/ \mathrm{kg}$ respectively.

Nicotinic acid was added to the diet at a level of $40 \mathrm{mg} / \mathrm{kg}$. Group I rats were fed ad lib. and group 2 rats were individually pair-fed with rats of group $\mathrm{I}$. Likewise, rats belonging to group 3 were fed $a d$ lib. and those of groups 4,5 and 6 were pair-fed with these rats.

At the end of 6 weeks of feeding, the rats were placed in metabolic cages and urine collected from each rat on three consecutive days in toluene and acetic acid. Rats were then killed by decapitation.

Male and female adult rats on stock diet weighing approximately $150 \mathrm{~g}$ each were used in the short-term experiment. L-tryptophan $500 \mathrm{mg} / \mathrm{kg}$ body-weight dissolved in warm $\left(37.5^{\circ}\right)$ normal saline (9 g sodium chloride/l) was injected intraperitoneally to one group of rats. Each rat was injected with 4-5 $\mathrm{ml}$ of the solution. The other group injected with a similar volume of saline served as controls. At $4 \mathrm{~h}$ after the injection the rats were killed.

Analytical methods. A sample of liver (approximately $0.3 \mathrm{~g}$ ) was homogenized with $\mathrm{IO}$ vol. cold trichloroacetic acid $(100 \mathrm{~g} / \mathrm{l})$, the homogenate filtered and nicotinamide nucleotides in the filtrate estimated fluorometrically by the alkali-ketone condensation method of Levitas et al. (1947).

Liver was homogenized with 9 vol. 0.14 M-potassium chloride at $2^{\circ}$ in $0.0025 \mathrm{M}$ sodium hydroxide in a glass-teflon homogenizer. The homogenate was centrifuged for $2 \mathrm{~min}$ at $600 \mathrm{~g}$ and the supernatant fraction used for the assay of tryptophan oxygenase activity according to the spectrophotometric method of Knox as described by Chiancone (1965).

Liver or kidney was homogenized in a cold room with 2 vol. $0.14 \mathrm{M}-\mathrm{KCl}$ for $3 \mathrm{~min}$, the homogenate centrifuged at $2^{\circ}$ for $20 \mathrm{~min}$ at $20000 \mathrm{~g}$ and the superantant solution treated with charcoal ( $150 \mathrm{~g} / \mathrm{l}$ enzyme solution) for $5 \mathrm{~min}$. The charcoal was subsequently removed by centrifuging at $10000 \mathrm{~g}$ at $2^{\circ}$. This preparation was used for the assay of quinolinate phosphoribosyltransferase, nicotinate phosphoribosyltransferase and picolinate carboxylase activities.

Quinolinate phosphoribosyltransferase activity was assayed by the microbiological method of Nishizuka \& Nakamura (1970) with Lactobacillus arabinosus (ATCC 8014) as described by Ghafoorunissa \& Narasinga Rao (1973). Nicotinate phosphoribosyltransferase activity was determined according to the method of Ikeda et al. (1965) except that $40 \mu \mathrm{mol}$ sodium fluoride was added to the incubation mixture to minimize the $5^{\prime}$-phosphoribosyl-I-pyrophosphate breakdown (Ismande, 1964). The product formed, nicotinic acid mononucleotide, was separated from the substrate nicotinic acid, on a Dowex $50 \times 2 \mathrm{H}^{+}$ (200-400 mesh) column $(0.5 \times 2 \mathrm{~cm})$ as described previously (Anasuya \& Narasinga Rao, 1975). Labelled nicotinic acid used as the substrate was completely retained on the column and only the nucleolides were eluted. Protein concentration in the enzyme preparations was 


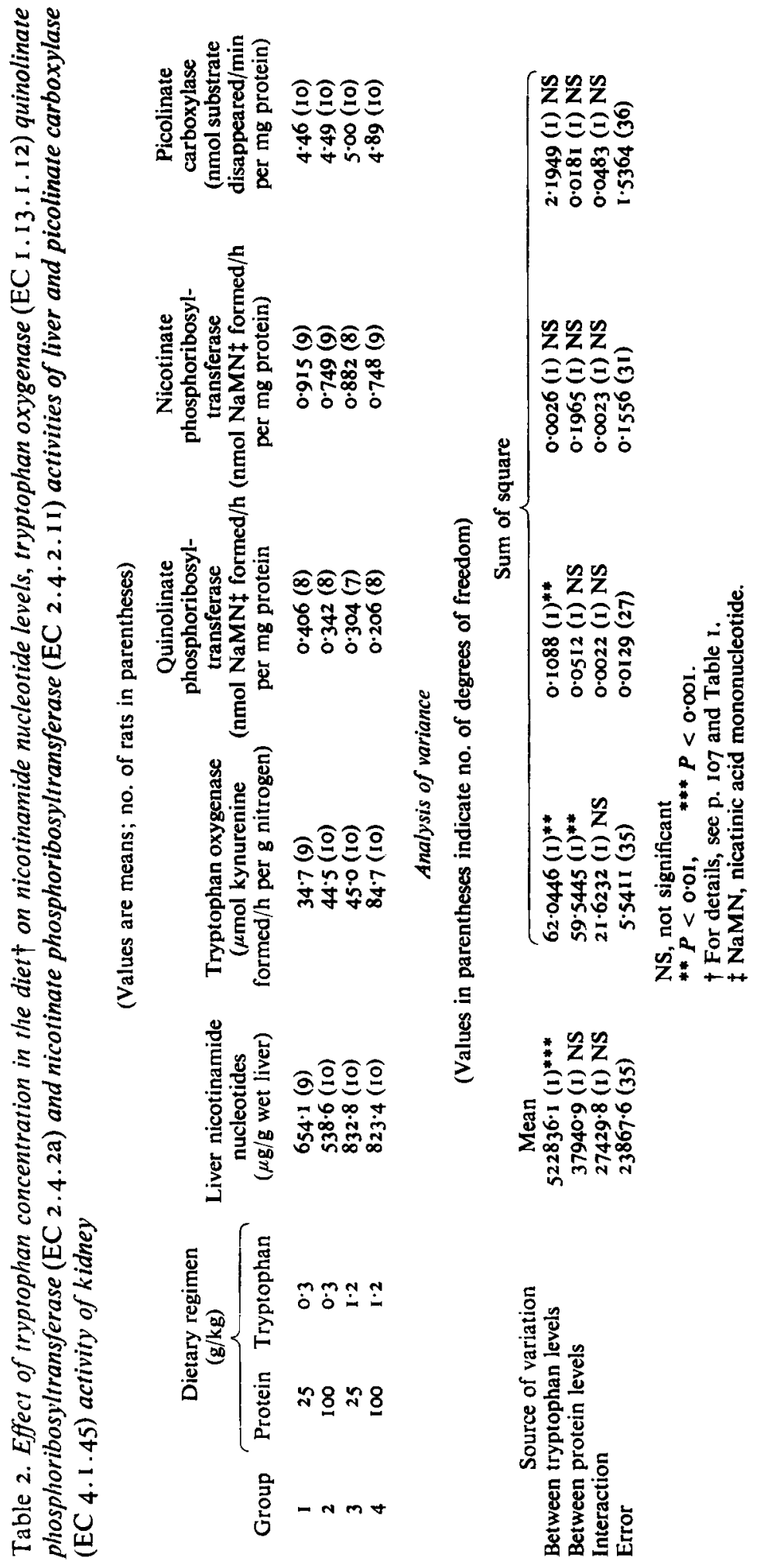


estimated by the method of Lowry et al. (I95I) using bovine serum albumin as the standard.

Urinary metabolites. Urinary quinolinic acid was decarboxylated to nicotinic acid by autoclaving with glacial acetic acid (I $7 \mathrm{M}$ ) for $2 \mathrm{~h}$ at a pressure of $103.4 \mathrm{kN} / \mathrm{m}^{2}$ (Henderson, 1949) and nicotinic acid was estimated by the microbiological method using L. arabinosus as the test organism (Freed, 1966). The difference between nicotinic acid before and after decarboxylation was taken as the amount of quinolinic acid in urine. $\mathbf{N}^{\prime}$-methylnicotinamide was estimated fluorometrically using alkali-ketone condensation method of Carpenter \& Kodicek (1950). Creatinine in urine was determined by Folin's method as described by Oser (1965).

Statistical analysis. Statistical analysis of results was carried out by analysis of variance. For this purpose only groups $1,2,3$ and 5 which forms a $2 \times 2$ factorial experiment were considered. The experiment was originally planned with equal number of animals (ten) in each cell. At the end of the experiment there was found to be some loss of observations in cells which is essentially random (in no way related to experimental variables). Hence the data was analysed by $2 \times 2$ factoral experiment by the method of unweighted means (Winer, 1974). Summary of analysis of variance tables are presented with the level of significance for mean sum of squares due to protein, tryptophan and interaction.

\section{RESULTS}

Levels of liver nicotinamide nucleotides and enzyme activities in liver and kidney of rats fed diets containing two levels of protein $(25$ and $100 \mathrm{~g} / \mathrm{kg})$ and two levels of tryptophan $(0.3 \mathrm{~g}$ and $1.29 \mathrm{~g} / \mathrm{kg})$ are shown in Table 2.

Liver nicotinamide nucleotides levels and tryptophan oxygenase levels increased while quinolinate phosphoribosyltransferase activity decreased with increase in tryptophan level in the diet at both the levels of protein. Analysis of variance of the results indicated that the level of tryptophan in the diet had a significant effect on liver nicotinamide nucleotides and on tryptophan oxygenase and quinolinate phosphoribosyltransferase activities. However, the influence of dietary protein level was significant only in the case of tryptophan oxygenase. The interaction between tryptophan level and protein level was not significant with any of these. Nicotinate phosphoribosyltransferase activity in liver and picolinate carboxylase activity in kidney remained unaltered at both protein levels with different tryptophan concentrations in the diet.

At adequate protein levels ( $100 \mathrm{~g} / \mathrm{kg}$ ) on increasing the tryptophan level from $0.3-0.6 \mathrm{~g} / \mathrm{kg}$ significant increase was observed only in the levels of liver nucleotides $(726.1 \pm 16.63 \mathrm{SE} \mu \mathrm{g} / \mathrm{g}$ wet liver) and tryptophan oxygenase activity (6I.5 $\pm 5 \cdot 40 \mu \mathrm{mol}$ kynurenine formed/h per $\mathrm{g}$ wet liver). At this protein level an increase in tryptophan level from $1 \cdot 2$ to $2 \cdot 4 \mathrm{mg} / \mathrm{kg}$ did not cause any change either in the nicotinamide nucleotides or in any of the enzymes.

Urinary excretion of quinolinic acid and $N^{\prime}$-methyl-nicotinamide in rats given different levels of tryptophan $(0.3 \mathrm{~g}$ and $1.2 \mathrm{~g} / \mathrm{kg})$ at two protein levels $(25 \mathrm{~g}$ and $100 \mathrm{~g} / \mathrm{kg})$ are given in Table 3.

Analysis of variance of urinary excretion results indicated that the effect of increasing tryptophan level or protein level in the diet on the excretion of these two metabolites was highly significant. The interaction between tryptophan and protein levels was also significant.

Quinolinic acid excretion increased with increase in tryptophan level in the diet. At the corresponding tryptophan levels in the diet excretion of these metabolites was higher on a protein restricted diet $(25 \mathrm{~g} / \mathrm{kg})$ than on adequate protein level $(100 \mathrm{~g} / \mathrm{kg})$. However, increase in quinolinic acid excretion was more striking when tryptophan concentration was increased from $0.3 \mathrm{~g}$ to $1.2 \mathrm{~g} / \mathrm{kg}$ on a protein restricted diet.

On a protein restricted diet $N$-methylnicotinamide excretion increased markedly when tryptophan concentration was increased from $0.3-1.2 \mathrm{~g} / \mathrm{kg}$ diet. On the other hand in rats 
Table 3. Effect of tryptophan level in the diet $\dagger$ on the urinary excretion ( $\mu \mathrm{g} / \mathrm{mg}$ creatinine) of quinolinic acid, $N^{\prime}$-methyl nicotinamide and nicotinic acid

(Values are means; no. of rats in parentheses)

\begin{tabular}{|c|c|c|c|c|}
\hline \multirow[b]{2}{*}{ Group } & \multicolumn{2}{|c|}{ Dietary regimen $(\mathbf{g} / \mathbf{k g})$} & \multirow[b]{2}{*}{ Quinolinic acid } & \multirow[b]{2}{*}{$\mathrm{N}^{\prime}$-methyl nicotinamide } \\
\hline & Protein & Tryptophan & & \\
\hline I & 25 & 0.3 & 3·I (8) & $26 \cdot 0(8)$ \\
\hline 2 & 100 & 0.3 & $2 \cdot 4(10)$ & 24.8 (10) \\
\hline 3 & 25 & $I \cdot 2$ & $61 \cdot 9(9)$ & I $12.6(9)$ \\
\hline 4 & 100 & $1 \cdot 2$ & 6.4 (Io) & $18 \cdot 6$ (10) \\
\hline
\end{tabular}

Analysis of variance

(Values in parentheses indicate no. of degrees of freedom)

Source of variation Mean

Between tryptophan levels

Between protein levels

Interaction

Error

\begin{tabular}{|c|c|}
\hline \multirow[t]{2}{*}{ Mean } & Sum of \\
\hline & $\begin{array}{c}9055 \cdot 2(1)^{* * *} \\
7235 \cdot 5(1)^{* * *} \\
6892 \cdot 4(1)^{* * *} \\
371 \cdot 45(33)\end{array}$ \\
\hline \multicolumn{2}{|c|}{$\begin{array}{l}\text { *** } P<0.001 \text {. } \\
+ \text { For details, see p. J07 and Table I. }\end{array}$} \\
\hline $\begin{array}{l}\text { injection ( } \\
\text { (EC I.I3 }\end{array}$ & $\begin{array}{l}\text { mg/kg body-weight) on } \\
\text { 2) and quinolinate p }\end{array}$ \\
\hline \multicolumn{2}{|c|}{ Mean values with their standard errors) } \\
\hline $\begin{array}{l}\text { nicotinamide } \\
\text { tides }(\mu \mathrm{g} / \mathrm{g} \text { wt } \\
\text { liver })\end{array}$ & $\begin{array}{c}\text { Tryptophan oxygenase } \\
\text { ( } \mu \text { mol kynurenine } \\
\text { formed/h per } \mathrm{g} \\
\text { nitrogen })\end{array}$ \\
\hline SE & Mean \\
\hline $\begin{array}{l}36 \cdot 78 \\
81 \cdot 64\end{array}$ & $\begin{array}{l}25 \cdot 53 \\
165 \cdot 5\end{array}$ \\
\hline
\end{tabular}

\begin{tabular}{|c|c|c|c|c|c|c|}
\hline \multirow[b]{2}{*}{ Group treatment* } & \multicolumn{2}{|c|}{$\begin{array}{l}\text { Liver nicotinamide } \\
\text { nucleotides }(\mu \mathrm{g} / \mathrm{g} \text { wt } \\
\text { liver })\end{array}$} & \multicolumn{2}{|c|}{$\begin{array}{c}\text { Tryptophan oxygenase } \\
\text { ( } \mu \text { mol kynurenine } \\
\text { formed/h per } \mathrm{g} \\
\text { nitrogen })\end{array}$} & \multicolumn{2}{|c|}{$\begin{array}{c}\text { Quinolinate } \\
\text { phosphoribosyltrans- } \\
\text { ferase (nmol formed/h } \\
\text { per mg, protein) } \\
\mathrm{NaMN} \dagger\end{array}$} \\
\hline & Mean & SE & Mean & SE & Mean & $\mathbf{S E}$ \\
\hline $\begin{array}{l}\text { Saline injection } \\
\text { L-tryptophan injection }\end{array}$ & $\begin{array}{r}822 \cdot 2 \\
1151 \cdot 0\end{array}$ & $\begin{array}{l}36 \cdot 78 \\
8 I \cdot 64\end{array}$ & $\begin{array}{l}133 \cdot 5 \\
694^{\circ} I\end{array}$ & $\begin{array}{l}25 \cdot 53 \\
165 \cdot 5\end{array}$ & $\begin{array}{l}0.39 \\
0.32\end{array}$ & $\begin{array}{l}0.053 \\
0.038\end{array}$ \\
\hline
\end{tabular}

Table 4. Effect of L-tryptophan injection ( $500 \mathrm{mg} / \mathrm{kg}$ body-weight) on nicotinamide nucleotide levels, tryptophan oxygenase (EC I.13.1.12) and quinolinate phosphoribosyltransferase (EC 2.4.2a) activities of liver

Statistical significance of differences between group for liver nicotinamide nucleotide: group $\mathbf{A} v$. group B, $P<0.01$; for tryptophan oxygenase, group A $v$. group B, $P<0.05$.

* For details, see p. 108.

$\uparrow \mathrm{NaMN}$, nicotinic acid mononucleotide.

given an adequate protein diet when tryptophan level in the diet increased, $\mathrm{N}$-methylnicotinamide excretion decreased.

At the adequate protein level when dietary tryptophan level was increased from 0.3 to $0.6 \mathrm{~g} / \mathrm{kg}$ diet a significant alteration was found only in the excretion of $\mathrm{N}^{\prime}$-methylnicotinamide (14.0 $\pm 2.09 \mu \mathrm{g} / \mathrm{g}$ creatinine). However, when tryptophan level in the diet was increased from $\mathrm{I} \cdot 2$ to $2.4 \mathrm{~g} / \mathrm{kg}$ both quinolinic acid and $N^{\prime}$-methylnicotinamide increased markedly ( $19 \cdot \mathrm{I} \pm \mathrm{I} \cdot 95$ and $6 \mathrm{I} \cdot 2 \pm 8 \cdot \mathrm{I} 2 \mu \mathrm{g} / \mathrm{g}$ creatinine respectively), but levels did not reach anywhere near the levels observed in the protein restricted group. Excretion of nicotinic acid was not affected either by the protein level or by the tryptophan level.

Tryptophan injection brought about an increase in tryptophan oxygenase activity and in liver nicotinamide nucleotide levels, but liver quinolinate phosphoribosyltransferase activity remained unaltered (Table 4 ). 
DISCUSSION

It was reported earlier that activity of liver tryptophan oxygenase increased and that of quinolinate phosphoribosyltransferase decreased when protein level in the diet was increased (Satyanarayana \& Narasinga Rao, 1977). These alterations in the activities of these two enzymes in response to changes in dietary protein level could be attributed either to the effect of protein per se or to the consequent changes in the levels of tryptophan in the diet. Results presented here show that increasing the dietary tryptophan level increased tryptophan oxygenase activity in liver, indicating that it was the tryptophan concentration in the diet that brought about the changes. Changes in dietary tryptophan concentration in the diet did not significantly influence liver nicotinate phosphoribosyltransferase and kidney picolinate carboxylase activities.

Tryptophan oxygenase is an adaptive enzyme which is known to be induced by its own substrate (Knox \& Mehler, I95I; Feigelson \& Greengard, I962) and by corticosteroids. This enzyme is also under the feed-back control of the end products, NADH, NMN \& NA (Cho-Chung \& Pitot, 1967). The development of this enzyme in the young rat has been shown to be under glucocorticoid control (Roper \& Franz, I977). The present observation that tryptophan oxygenase activity increased with increasing dietary tryptophan level or with injection of tryptophan is consistent with the substrate inducible nature of this enzyme. However, results obtained in the present study demonstrate that dietary protein must be adequate for the optimum response of the substrate induction of tryptophan oxygenase. At low levels of dietary protein, the increase in this enzyme, in response to dietary tryptophan was not significant, suggesting that the substrate available for enzyme induction is limited on a low protein intake.

An important observation of this study is that the level of quinolinate phosphoribosyl activity can be altered by changing only the tryptophan level in the diet keeping the level of other amino acids (i.e. dietary $N$ ) constant provided the dietary protein level is not very low. It must be pointed out however that this effect of tryptophan is unlike the effect of dietary excess of leucine on this enzyme reported earlier (Ghafoorunissa \& Narasinga Rao, I 973). In the instance of leucine, excess of this amino acid $(30 \mathrm{~g} / \mathrm{kg})$ had to be added to the diet over the normal amounts of leucine present in the protein of the diet to cause a decrease in the level of this enzyme. But in the instance of tryptophan varying its level within the levels normally present in dietary proteins affected this enzyme.

Tryptophan, the first substrate in the chain of reactions leading to synthesis of nicotinamide nucleotides, thus controls the activity of quinolinate phosphoribosyltransferase which catalyses the conversion of quinolinic acid to nicotinic acid mononucleotide. This observation appears to be unique, since it is rare to observe an enzyme decrease with increase in level of a distant substrate. Chatagner (I964) reported that L-cystine sulphate decarboxylase (EC 4.I.I.29) decreased with an increase in the concentration of either protein or cystine in the diet.

The manner in which dietary tryptophan regulates the activity of quinolinate phosphoribosyltransferase is at present not clear. Although prolonged feeding of a high level of tryptophan in the diet reduces the activity of this enzyme level measured in vitro it was not affected during the few hours following intraperitoneal injection of tryptophan. This observation rules out any possibility of direct effect on this enzyme of either tryptophan or its metabolites. It also precludes any feed-back inhibition of this enzyme by NAD which increased following tryptophan injection. However, the possibility of this enzyme being affected in vivo by tryptophan injection needs to be considered. But, the fact that NAD levels increased significantly following tryptophan injection in fact suggests that the in vivo activity of this enzyme also may not have been affected following tryptophan injection. 
Another interesting observation in the present study was that the response of the biochemical measurements studied was related to the level of tryptophan in the diet. At $100 \mathrm{~g}$ protein $/ \mathrm{kg}$ level, the response of liver nicotinamide nucleotide level, tryptophan oxygenase and quinolinate phosphoribosyltransferase activities to dietary tryptophan were almost linear up to a dietary tryptophan concentration of $1.2 \mathrm{~g} / \mathrm{kg}$ diet beyond which these measurements were not markedly affected. On the other hand, excretion of quinolinic acid and $\mathrm{N}^{\prime}$-methylnicotinamide did not alter up to $\mathrm{I} \cdot 2 \mathrm{~g}$ tryptophan $/ \mathrm{kg}$ diet providing $100 \mathrm{~g}$ protein/ $\mathrm{kg}$ which represents the requirement of this amiro acid for the rat (Rama Rao et al. 1959). While the response of the two enzymes to the changes in tryptophan intake was linear below the level of its requirement, the excretion of urinary metabolites, quinolinic acid and $\mathrm{N}^{\prime}-$ methylnicotinamide representing disposal of tryptophan did not substantially alter below the requirement level but increased markedly when tryptophan intake was above the requirement level. Young et al. (1971) reported in human subjects that plasma tryptophan concentration increased sharply when tryptophan intake was increased above the requirement level. They suggested that the response of plasma levels of tryptophan can be used as a biochemical test to determine the tryptophan requirement in man. Our study suggests that estimation of urinary excretion of quinolinic acid and $\mathrm{N}^{\prime}$-methylnicotinamide may be useful in assessing the tryptophan nutritional status and its requirement.

The authors are grateful to Dr S. G. Srikantia, Director, National Institute of Nutrition, Hyderabad, for his keen interest and encouragement during this study. They also wish to acknowledge the help of $\mathrm{Mr} \mathrm{T}$. Ramnath in statistical analysis of the results.

\section{REFERENCES}

Anasuya, A. \& Narasinga Rao, B. S. (1975). Biochem. Med. 12, 365.

Carpenter, K. J. \& Kodicek, E. (1950). Biochem. J. 46, 421.

Chatagner, F. (1964). Biochem. biophys. Acta 81, 400.

Chiancone, F.M. (1 965). In Newer Methods in Nutritional Biochemistry, vol. 2, p. 249. [A. Albanese, editor]. New York and London: Academic Press.

Cho-Chung, Y.S. \& Pitot, H.C. (1967). J. biol. Chem. 242, 192.

Feigelson, P. \& Greengard, O. (1962). J. biol. Chem. 237, 3714.

Freed, M. (1966). In Methods of Vitamin Assay, 3rd ed., p. 169. [Association of Official Vitamin Chemists, editors]. New York: Interscience Publishers.

Ghafoorunissa \& Narasinga Rao, B. S. (1973). Biochem. J. 134, 425.

Henderson, L. M. (1949). J. biol. Chem. 18r, 677.

Ikeda, M., Tsuji, H., Nakamura, S., Ichiyama, A., Nishizuka, Y. \& Hayaishi, O. (1965). J. biol. Chem. 240, 1395.

Ismande, J. (1 964). Biochim. biophys. Acta 85, 255.

Knox, W. E. (1966). In Advances in Enzyme Regulation, v. 4, p. 287 [G. Weber, editor]. Oxford: Pergamon Press.

Knox, W. E. \& Mehler, A. H. (195I). Science N.Y. Ir3, 237.

Levitas, M., Robinson, J., Rosen, F., Huff, J. W. \& Perlzweig, W. A. (1947). J. biol. Chem. 167, 169.

Lowry, O. H., Rosebrough, N. J., Farr, A. L. \& Randall, R. J. (I95I). J. biol. Chem. 193, 265.

Majeurs, P. W. \& Kilburn, E. (1969). J. biol. Chem. 244, 6254.

National Research Council (1963). Rep. natn. Acad. Sci., Wash. no. 1100.

Nishizuka, Y. \& Nakamura, S. (1970). Meth. Enzym. 17A, 49 I.

Oser, B. L. (1965). In Hawk's Physiological Chemistry, 14th ed., p. 1 233. New York: McGraw-Hill.

Rama Rao, P. B., Chalam Metta, V. \& Connor Johnson, B. (1959). J. Nutr. 69, 387.

Roper, M. D. \& Franz, J. M. (1977). J. biol. Chem. 252, 4354.

Satyanarayana, U. \& Narasinga Rao, B. S. (1977). Br. J. Nutr. 38, 39.

Schimke, R. T. (1973). Adv. Enzymol. 37, 135.

US Pharmacopoeia XVII (1965), p. 862 .

Winer, B. J. (1974). Statistical Principles in Experimental Design, 2nd ed., pp. 445-449. New York: McGrawHill.

Young, V. R., Hussein, M.A., Murray, E. \& Scrimshaw, N. S. (197I). J. Nutr. 1or, 45. 